\title{
THE GOVERNER OF THE BEST CITY BASED ON A CLASSICAL MASTER PIECE ON MANAGEMENT AND POLITICS: AN ANALYSIS OF EL-MEDINET'UL-FAZILA
}

\section{Bilge Kağan Şakacı *}

* Eskişehir Osmangazi Üniversitesi İIBF Siyaset Bilimi ve Kamu Yönetimi E-mail:ksakaci@gmail.com

Copyright (C) 2016 Bilge Kağan Şakacı. This is an open access article distributed under the Eurasian Academy of Sciences License, which permits unrestricted use, distribution, and reproduction in any medium, provided the original work is properly cited.

\begin{abstract}
El-Medînetu'l-Fâzila was written between 940-942 by Farabi. It is one of the most important classical piece in the fields of politics and administration. It explains the Farabi's approaches on city and society. In El-Medinetu'l Fazila the work of Farabi (870-950), who is a well-known scholar in politics and philosophy, the concepts of virtue and happiness are based on ethics. According to him, the ultimate goal of the state should be to establish virtue and happiness. In this context, Farabi argues that a leader's competency must be based on physical, personal and moral qualities. Farabi attributes 12 qualifications to the first leader and governor of the virtuous city. On the other hand, it is unlikely for someone to embody all these qualities in one person. If the successors of the first leader should pursue the established system and laws if they are not possess required capabilities. It was an important guiding source on the central and local governments. This study is a theoretical research based on the reladed literature. While ElMedinetu'l Fazila is the primary data source for the discussions, the research also uses secondary sources on this master piece to strengthen the arguments of the study.
\end{abstract}

Keywords: El-Medinet’ül-Fazila, Farabi, City, Leader, Governer.

\section{YÖNETIM VE SIYYASET ALANINDAKİ BİR KLASİK TEMEL ESER ESASINDA EN MÜKEMMEL ŞEHRIN YÖNETICİSİ: EL- MEDINNET'ÜL-FAZILA'YA DAİR ANALİZ}

\section{ÖZET}

El-Medînetü'1-Fâzıla 940-942 yılları arasında Farabi tarafından yazılmıştır. Politika ve yönetim alanındaki en önemli klasik eserlerden biridir. Şehir ve toplum hakkındaki Farabi'nin yaklaşımını açıklar. Bir siyaset ve felsefe bilgini olan Farabi (870-950)'nin El-Medinetü'1 Fâzıla isimli eserinde de, erdem ve mutluluk kavramlarının etik yönetim üzerinden temellendirildiği görülür. Ona göre devletin nihai amacı erdem ve mutluluğu tesis etmek olmalıdır.Bu bağlamda liderin nitelik olarak fiziksel, kişisel ve ahlaki olarak yeterli olması 
gerektiğine vurgu yapıldığı görülmektedir. Farabi erdemli şehrin ilk lideri ve yöneticisinde bulunması gereken 12 nitelikten bahsetmektedir. Öte yandan bütün bu yeteneklerin bir kişide toplanması güç olduğundan ve söz konusu niteliklere sahip biri bulunmazsa ilk liderden sonra gelen yöneticilerin, kurulmuş olan mevcut sistemi ve kanunları devam ettirmesi gerektiği ifade edilmektedir. Merkezi ve yerel yönetimler açısından önemli bir rehber kaynak rolüne sahipti. Çalışma literatür taraması kaynaklı teorik bir çalışmadır. Makaledeki tartışmada birincil veri kaynağı olarak El-Medinet'ül-Fazıla kullanılırken, araştırma aynı zamanda şaheserle ilgili ikincil kaynakların kullanımıyla güçlendirilmektedir.

Anahtar Kelimeler: El-Medinet'ül-Fazila, Farabi, Şehir, Lider, Yönetici

\section{Giriş}

Farabi, Türkistan'da Farb (Otrar) civarındaki Vesic kasabasında doğmuştur. Dünyaca ünlü bir Türk-İslam fillozofudur. 870-950 yılları arasında yaşamıştır. Öncelikle memleketinde başladığı tahsilini tahminen 20 yaşlarından sonra Bağdat'ta sürdürmüştür. Devamında Mekke, Halep, Şam, Misır ve bazı kaynaklara göre Harran'da da bulunmuştur. Yohanna bîni Hayaln ile Abu Bişir Matta en büyük üstadlarıdır. Bu alimler sayesinde Yunan alim ve filozofların ilim ve felsefi fikirlerini esaslı bir şekilde öğrenmiştir. Farabi, bir doğa bilimci, ruh bilimci, müzik alimi, matematikçi, doktor ve ahlakçıdır. Zamanında varlık göstermiş bütün ilimler konusunda bilgi ve fikir sahibidir. Ancak her şeyden önce bir mütefekkir, bir filozoftur. Siyaset ilmi, hukuk felsefesi sahasında da bir alimdir. Büyük kısmı bağımsız eser olan yüzden fazla eser bırakmıştır. Kalanları ise Yunan filozoflarının eserlerini açıklama ve yorumlamaya ayrılmıştır (Arsal, 1945: 620-621; Çınar, 2001: 77-80). Ana kaygıs1 "etik-politik" olan bir filozoftur. Kendinden önce gelen filozofları kendine göre ele almakta ve onları yorumlayıp değerlendirmektedir. Farabi’ye göre eski filozoflar çoğunlukla sembolik ifadeler kullanmışlardır (Olguner, 1987: 30). Ansiklopedi tarzında kaleme aldığı eserleri, şerhleri ve eleştirileri bulunmaktadır. Siyaset felsefesine dair görüsslerini ağırlıklı olarak ele aldığı eserleri Fusûlu'l-Medenî, el-Medînetu'lFâzıla, es-Siyâsetu'l-Medeniyye ve Tahsîlu's-Saâde'dir (Vural, 2010: 46; Şahin, 2010: 114).

Farabi'nin tüm düşünce sistemini yöneten iki temel inancı vardır.

-Ciddi bir görüş farklılığının gerçek filozoflar arasında olamayacağı;

-Gerçek felsefe ile doğru bir şekilde anlaşılan din arasında bir çatışma olamayacağı görüşleridir.

Birinci görüş onu Platon ve Aristoteles'in temelde "bir ve aynı kaygılardan hareketle, bir ve aynı amaçla, bir ve aynı bir bilim değerinde olan” felsefe sistemi kurmuş olduklarını düşünmeye götürür. Hatta bunun aksi olan fikri savunanların görüşlerini yanlışlamak için bir eser kaleme alır. (“Al-Cam' bayn Rayay al-Hakîmayn Eflâtun al-İlâhi ve Aristûtâlîs” isimli risalesi Mahmut Kaya tarafından "Eflatun ve Aristoteles' in Görüşlerinin Uzlaştırılması" adıyla Türkçe'ye çevrilmiştir.) İkinci görüşü ise onun, gerçek felsefe ile doğru bir şekilde anlaşılan din arasında; hakiki bilgi, bilim ile doğru inanç, aydınlatılmış inanç arasında hiçbir görüş ayrılığı, çatışma olamayacağı, olmaması gerektiği görüşüne götürür (Arslan, 1997: 8-9).

$\mathrm{O}$, iyi eğitim görmüş, kültürlü okuyucularına, Walzer'in deyimiyle "kendileri bizzat felsefe yapmamakla birlikte felsefeyi anlamaya muktedir okuyucuları"na ulaşmaya çalışmıştır (Akt. Arslan, 1997: 10). Görüşlerini eğitim görmemiş sokaktaki insana göre formüle etmemiştir (Arslan, 1997: 8-9). Farabi hakkında yazı yazmış olan müslim ve gayri müslim yazarlar filozofun birleştirici ve uzlaştırıcı özellikleri üzerinde fazlaca durdukları halde onun çok daha önemli olan tahlilci özelliği üzerinde yeterince durmamışlardır (Danışman, 1990: 11). 
El-Medînetü'1 Fâzıla eserini Farabi'nin 940-942 tarihleri arasında yazdığ1 bildirilmektedir. Onu Bağdat'ta yazmaya başlamış, Şam'da tamamlamıştır. Daha sonra bu kitabı tekrar gözden geçirip, bölümlerin başlığını koymuştur. Bu en son eseridir. Bu çalışma, Farabi'nin En Mükemmel Şehrin Yurttaşlarının Görüşlerinin İlkeleri isimli eserinin çevirisi esas alınarak yapılmıştır. Arapçası Mabâdi Arâ Ahl al-Madîna al-Fâdıla adını taşıyan bu eseri En Mükemmel Toplumun (veya Erdemli Toplumun veya İdeal Toplumun) Yurttaşlarının Görüşlerinin Ana Özellikleri (Arâ) ${ }^{1}$ olarak da Türkçe’ye çevirmek mümkündür.

Farabi'nin dili son derece veciz, kısa, özlü ve tekniktir. Geniş açıklamalar, geliştirilmiş akıl yürütme zincirleri vermekten hoşlanmamaktadır. Ayrıca benimsediği görüşlerin kaynakları, hücum ettiği düşüncelerin sahipleri vd. hakkında da herhangi bir açıklama yapmamaktadır. Özellikle Arâ'da bu iki nitelik açık bir biçimde kendini göstermektedir. O savunduğu fikirlerin ilk kez kim tarafından ifade edilmiş olduğuyla veya çağdaşlarından hangisinin onu daha iyi sergilemiş olduğu meselesiyle ilgilenmemektedir. Onun için önemli olan ortadaki sorun ile, aydınlığa kavuşturmayı arzu ettiği konu ile ilgili olan gerçeğin kendisidir.

Farabi, "Yunan tarzında İslam felsefesi (la philosophie hellenisante) geleneğinin başlangıcında olan, etkileri daha sonraki filozoflar üzerinde (örneğin İbni Sina ${ }^{2}$, İbni Tufetl vs.) son derece belirleyici olmuş" bir filozoftur. İslâm'da siyaset felsefesi alanında belli bir geleneğin, "medenî siyaset" geleneğinin başlatıcısı ve önemli temsilcisidir (Arslan, 1997: 2229). Farabi, kendi dönemindeki mezhep ve firkaların hiçbirinin aleyhinde ve lehinde bir duruş sergilememiştir (Kaya, 2010: 16).

El-Medînetü'l-Fâzıla (Mabâdı' Arâ Ahl Al-Madına Al-Fâdıla) sadece yazıldığı devir için değil, günümüz için de yol gösterici rolüne sahiptir. Öte yandan eserdeki yönetici tipi hem yerel yönetim hem de merkezi yönetim için önemlidir. Bu çerçevede çalışma kapsamında "Erdemli şehrin yöneticilerin nasıl olması gerektiğine dair El-Medînetü'l-Fâzıla'dan alınabilecek öğütler" inceleme nesnesidir.

\section{Farabi’nin İdeal Şehrinin Yöneticisi}

Farabi'ye göre; insanın nihai amacı "mutluluk ve erdeme ulaşmak" olmalıdır (Demirel, 2014: 359). En yüksek mutluluğun dünyada gerçekleşmesine ve sonrasında ahirette sınırsız/sonsuz mutluluğun elde edilmesine neden olacak yönetim erdemli yönetim ve onun erdemli başkanıdır (Çetinkaya, 2006b: 43). Çalışma kapsamında önce Farabi'nin görüşleri verilecek ardından da bunların açıklama ve eleştirilerine yer verilecektir.

1. Her insan birçok şeye muhtaç olan bir yaratılışta varlığa gelmiştir. Bu ihtiyaçları kendilerini devam ettirmek ve en üstün mükemmelliğini elde etmek içindir. Bunun için o, her biri kendisinin özel bir ihtiyacını karşılayacak birçok insana muhtaçtır. Toplumun bütününün katkısı neticesinde herkesin varlığını devam ettirmek ve mükemmelliğe erişmek için ihtiyaç duyduğu şeyler sağlanmış olur. İnsanların çok sayıda varlığa gelmesinin ve dünyanın oturulabilir kısmında bazısı mükemmel, bazısı eksik, kusurlu olan insani toplumlar kurarak bir araya gelmelerinin nedeni budur (Farabi, 1997: 99-100). İnsan doğal yaratılışı bakımından toplumsal bir varlıktır. Hem daha doğrudan ve inkar edilmez ihtiyaçlarını tatmin etmesi için hem de başka şekilde kaderini gerçekleştirmesi ve betimlenen nihai mükemmelliğine ulaşması mümkün olmadığından toplum içinde yaşamak zorundadır. İnsani varlıkların işbirliği zorunlu olduğundan yukarıda bahsi geçen çok sayıda ve farklı insani varlıklar meydana gelmiştir. Tam,

\footnotetext{
${ }^{1}$ Eser ile ilgili olarak bundan sonra kısaltılmış olarak "Arâ” kelimesi de kullanılacaktır.

${ }^{2}$ İbni Sina derli toplu şekilde meydana getirdiği mantık koleksiyonu sayesinde hemen hemen yegane meşhur mantıkçı olarak İslam dünyasında en büyük egemenliği temin etmiştir (Keklik, 1969: 48).
} 
mükemmel olarak adlandırılan toplumlar kendi kendine yeten toplumlardır (Walzer, 1997: 241242). Burada bahsi geçen nitelik bütün insanları kapsar. İnsanlığın bir kısmına özgü olan bir şey değildir (Şirvani, 1950: 448).

2. Mükemmel toplumlar büyük, orta ve küçük olmak üzere üç çeşittir. Oturulabilir dünyanın bütününde bütün milletlerin bir araya gelmesi "büyük toplum" dur. Oturulabilir dünyanın bir parçasında tek bir milletin bir araya gelmesi "orta toplum" dur. Herhangi bir milletin oturduğu topraklar üzerinde tek bir şehir halkının bir araya gelmesi "küçük toplum”dur. Bir köy halkının, mahalle halkının, bir sokakta oturanların, bir ev halkının (en küçük bir birliktir.) bir araya gelmesi kusurlu, eksik bir toplumu meydana getirir. Mahalle ve köyün her ikisi de şehir için vardır. Köyün şehirle ilişkisi, ona hizmet ilişsisidir. Mahalle ise şehrin bir parçası olarak onunla ilişki içindedir. Sokak mahallenin, ev ise sokağın bir parçasıdır. Şehir, "bir milletin yaşadığı toprakların bir parçası, millet üzerinde yaşanan dünyanın bütün toplumlarının bir parçasıdır" (Farabi, 1997: 100). ${ }^{3}$ Toplumların listesine bakıldığında Walzer (1997: 242-243)'e göre, şehir devletlerin, millet devletlerin ve "dünyanın oturulabilir tüm bölgelerini içine alması mümkün olan bir devletin" var olduğunu öğrenebilmekteyiz. Küçük bir şehrin boyutlarıyla mükemmel devletin sınırlandırılmış olması gerekmez. O Roma ve Sasani İmparatorluğu gibi büyük bir imparatorluğa benzer bir şey veya hatta evrensel bir dünya devleti olabilir.

3. En üstün iyilik ve mükemmelliğe ilkin ancak şehirde ulaşılabilir. Şehirden daha eksik olan bir toplulukta ulaşılamaz. Öte yandan bir şehrin kötü olan bir takım amaçların elde edilmesi için insanların birbirlerine yardımda bulundukları bir varlık olarak da kurulması ihtimal dahilindedir. Bundan ötürü "mutluluğun her şehirde elde edilmemesi mümkündür." $\mathrm{O}$ halde erdemli, mükemmel bir şehir (madınâ fâdıla), insanları kendileriyle gerçek anlamda mutluluğun elde edildiği şeyler için birbirlerine yardım etmeyi amaçlayan bir şehirdir. Erdemli, mükemmel bir toplum ise, insanları mutluluğu elde etmek için birbirlerine yardım eden toplumdur. Erdemli, mükemmel bir millet ise bütün şehirleri kendileriyle mutluluğun elde edildiği şeyler için birbirlerine yardım eden bir millettir. "Erdemli, mükemmel evrensel devlet de ancak içinde bulundurduğu bütün milletlerin mutluluğa erişmek için birbirlerine yardım ettikleri zaman ortaya çıkar" (Farabi, 1997: 100-101). Burada kitabın adında da geçen "medine" (madina) kelimesinin anlamının analiz edilmesinin yararlı olacağı kanısındayız. Medine hem herhangi bir tür örgütlenmiş toplum, etkili bir biçimde yönetilen ve politik olarak bağımsız olan herhangi bir "res publica", hem de şehir devleti "polis" anlamına gelebilir (Walzer, 1997: 243). Arapça' da medine sözcüğü yerleşmek, şehir kurmak, kale inşası yapılan her yüksek yer gibi anlamlarda karşılık bulmaktadır. Kur'an'da ise medine ifadesi, devletten çok coğrafi bütünlüğü tanımlayan şehir anlamında kullanılmaktadır (Çetinkaya, 2006a: 40).

Sure: 15. Hicr, Ayet: 67 "Şehir halkı sevinerek geldiler."

Sure: 36. Yasin, Ayet: 20 "Şehrin öbür ucundan bir adam koşarak geldi ve şöyle dedi: 'Ey kavmim! Bu elçilere uyun.” (http://kuran.diyanet.gov.tr/)

Ancak kimi yazılı metinlerde devletin karşılığı olarak da medine kelimesi yer almaktadır (Çetinkaya, 2006a: 40). Farabi şehir (medine) kelimesini, "belli bir gaye ile, bir şehirde toplanmış olan kimselerin meydana getirdiği 'topluluk' manasında” kullanmaktadır (Ateş, 1990: 141). Farabi kendi zamanında mevcut olan milletlere örneğin Türklere ve Arap bedevilere atıfta bulunur. En mükemmel insan da olsa hiçbir insani varlığın, örgütlenmiş bir topluluk içinde karşılıklı işbirliği olmadıkça mutluluğa ve mükemmelliğe ulaşamayacağı artık tesis edilmiştir. Ancak bir ev veya bir sokak veya şehrin bağımsız bir mahallesi, "kırsal bölgedeki köyler gibi, kendi kendine yeterli değildir." Çünkü onlar bu amaç için gereğinden

\footnotetext{
${ }^{3}$ Farabi'nin eserinde açık bir şekilde “kaç özün birleşmesinden il, kaç ilin birleşmesinden ulus, kaç ulusun birleşmesinden de uluslar birliğinin meydana geldiğgi” belirtilmemektedir (Kars, 2006: 28).
} 
çok küçüktürler: Sokaklar ve evler, mahallenin alt bölümleri; mahalle ise şehrin bir alt bölümüdür. "Eğer insanlar 'en yüksek iyilik'i elde etmek istiyorlarsa, hiç olmazsa bir şehir toplumu büyüklüğündeki bir topluma ihtiyaç vardır” (Walzer, 1997: 244-246).

4. Erdemli, mükemmel şehir "bütün organları canlı varlığın hayatını tam kılmak ve onu bu durumda tutmak için birbirleriyle yardımlaşan tam ve sağlıklı bir bedene benzer." Şehrin parçaları da bedenin organları gibi yaratılış bakımından birbirinden farklı ve bu parçaların doğal yetenekleri birbirinden üstündür. Şehirde de, bedenin amir organı kalp ve derece bakımından bu amir organa yakın olan organların olması gibi, amir olan bir insan ve dereceleri bu insana yakın olan başka insanlar vardır. Bu insanların her biri, kendileriyle bu amirin amacına uygun olarak fiilde bulundukları bir yetenek ve yatkınlığa sahiptir. Bu insanlar, derece bakımından birinci sıradadırlar. Bu birinci sıradaki insanların altında, onların amaçlarına uygun olarak eylemlerini gerçekleştiren başka insanlar gelir ki onlar da ikinci sıradadırlar. İkinci sıradakilerin de altında ikinci sırada bahsi geçen insanların amaçlarına uygun olarak eylemlerini yapan insanlar bulunur ve şehrin kısımları, başkalarının amaçlarına uygun olarak eylemlerini yapan, ancak kendi amaçlarına uygun olarak kimsenin eylemde bulunmadığ 1 gruplara ulaşıncaya kadar böyle bir sıra içinde aşağıya doğru iner. $\mathrm{Bu}$ sonuncular, başkaları tarafindan hizmet edilmeksizin başkalarına hizmet edenlerdir. Bundan dolayı da onlar, en değersiz, en alt sırada bulunan şeylerdir. Bedenin organları doğaldır ve onların sahip olduğu yetenekler, doğal kuvvetlerdir. Buna karşın şehrin kısımları doğal olmakla beraber, bu kısımların kendileriyle şehirde eylemlerini meydana getirdikleri yetenek ve yatkınlıklar doğal değil, iradi şeylerdir. Fakat, şehrin kısımları, tabiat bakımından, "insanların şu şeyi değil de bu şeyi yapmalarının kendileri için daha uygun olduğu" birbirinden farklı niteliklerle varlığa gelmişlerdir. Bununla birlikte genelde onlar sadece sahip oldukları doğal yaratılışları ile değil, daha çok sanatlar ve benzerleri gibi kazanmış oldukları iradi yatkınlıkları ile şehrin kısımlarıdır. Bedenin organlarında bulunan doğal kuvvetlere, şehrin kısımlarında bulunan iradi yatkınlık ve yetenekler karşılık gelir (Farabi, 1997: 101-102). En iyi şehir orantılı eşitliğe, gerçek adalete dayanır. Bu şehirde "herkes doğal yaratılışı itibariyle gerçekleştirmeye muktedir (erkli) olduğu görevi yerine getirir ve gerçekleştirdiği șeye uygun olarak da hakkettiği dereceyi işgal eder." Farabi, sağlıklı bir vücudun işleyişi ve tüm evrenin hiyerarşik düzeni ile doğru bir şehir yapısını karşılaştırmaktadır. Toplum kendi kendine ortaya çıkmaz; o ancak insanın bilinçli çabası ile kurulabilir. Farabi'nin tabiatın "hiyerarşik yapısını herkes tarafından kabul edilen bir şey olarak göz önüne aldığ1 ve onun mükemmel şehrin oluşumunda da takip edilmesi gerektiğini bir postüla olarak ileri sürdüğü noktasına" dikkat etmek gerekir. İnsan vücudu ile göksel düzen arasında başka yerlerde karşılaştırma yapmıştır. Burada "bedenin kısımlarının ortak amaçları için işbirliği, onların derece bakımından doğal farklılıkları ve kalbin yönetici işlevleri üzerinde özel olarak durmaktadır.” Bu işbirliği aşağı dereceden organlar tarafindan yukarı dereceden organların taklit edilmesi olarak tasvir edilmektedir. Bedenin kısımları veya organlarının hangileri olduğu özel olarak belirtilmemektedir. Kitapta şehrin farklı kısımları da özel olarak belirtilmemektedir. "Nasıl ki kalp yalnız başına vücudu idare etmekteyse, ideal şehrin de ancak tek bir yönetici tarafından idare edilebilir." Filozoflar grubu gibi bir yapının yönetmesi imkanı burada göz önüne alınmamaktadır (Walzer, 1997: 247-248). Bu çerçevede şehir birimleri de her organ gibi kendi işiyle meşguldür. Demirel (2014: 362)'e göre "kuvvetler ayrılığ 1 ilkesi" geçerlidir. Şehrin kurumlarında ve kurumlararası ilişkilerde organlararası ast-üst düzenine dayalı hiyerarşik bir düzen bulunmaktadır. Şehir idaresini farklı organlar oluşturmakta, fakat bir bütünlük arz etmektedir.

5. Kalp nasıl ki ilk olarak meydana gelirse, daha sonra bedenin diğer organlarının varlığının, onların kuvvetlerinin meydana gelişinin, onların kendilerine özgü olan varlık sırası içinde ortaya çıkışlarının nedeni olursa ve bu organlardan biri bozulduğunda kalbin kendisi bu bozukluğun giderilmesini sağlayan ise, aynı şekilde ilk olarak şehrin yöneticisinin varlığa 
gelmesi, sonra şehrin kısımlarının, bu kısımların iradi yatkınlıklarının meydana gelişinin, onların kendilerine özgü olan varlık sırası içinde ortaya çıkışlarının nedeni olması gerekir. Şehrin herhangi bir parçası bozulduğunda bu bozukluğu giderme araçlarını sağlayan da odur. Bedende amir organa yakın olan organlar, bu amir organın hedefine uygun olan doğal eylemler arasında, doğaları gereği, onların en şereflilerini yaparlarsa, onların altında bulunan organlar ise daha az şerefli eylemleri yaparlarsa ve bu şekilde en aşağı cinsten eylemleri yapan organlara kadar ulaşılırsa; aynı şekilde, şehirde şehrin yöneticisine emredicilik bakımından yakın olan kısımlar en şerefli iradi eylemleri, onların altında bulunanlar daha az şerefli iradi eylemleri gerçekleştirirler ve bu şekilde en aşağı cinsten iradi eylemleri yapan kısımlara kadar ulaşılır. $\mathrm{Bu}$ tür eylemlerin aşağılığı, bayalığ 1 , bazen son derece faydalı olmalarına rağmen, örneğin mesane ve kalın bağırsağın eyleminde olduğu gibi, onların konularından ileri gelir. Bazen ise onların faydasız olmalarından veyahut yapılmalarının çok kolay olmasından kaynaklanır. Aynı durum şehir ve parçaları doğaları gereği birbiri ile düzenli, derli toplu bir şekilde bağlanmış, düzenlenmiş olan her bütün için söz konusudur. Çünkü bunlar, diğer parçalara göre bir amire, yöneticiye sahiptirler (Farabi, 1997: 103). Burada bedenle yapılan karşılaştırma sürdürülmekte ancak vurgu ideal şehrin yöneticisi üzerine aktarılmaktadır. Farabi'nin politik teorisinin ana sorunu, doğru yöneticiyi tanımlamaktır. Çünkü her şey ona bağlıdır. Yönetici, şehrin kısımlarının varlığının nedeni olduğu gibi şehrin şehir olarak da varlığının da nedenidir (Walzer, 1997: 249).

6. Bütün varlıkların da durumu böyledir. Çünkü İlk Neden'in diğer varlıklara nisbeti, erdemli şehrin hükümdarının, onun diğer kısımlarına olan nisbeti gibidir. Onlar içindeki en sondaki, kendisinin makam bakımından biraz üstünde olanın amacını takip eder. İkinci de kendi payına makam bakımından kendi üstündekinin amacını, üçüncü makam bakımından kendisinin üstünde bulunanın amacını takip eder ve kendileri ile İlk Neden arasında artık başka bir varlığın bulunmadığı varlıklara ulaşıncaya kadar bu böylece sürüp gider. Düzene uygun olarak bütün varlıklar İlk Neden'i takip ederler. "Varlıklarını kendisine borçlu oldukları şeye ta başından itibaren sahip olanlar, İlk Neden'i ve onun gayesini ta başından itibaren taklit ederler." Onlar bundan dolayı sonsuz mutluluğu tadarlar ve en yüksek makamları işgal ederler. "Varlıklarını kendisine borçlu oldukları şeye ta baştan itibaren sahip olmayanlar, elde etmeyi umdukları bu şeye kendisiyle yöneldikleri bir kuvvete sahiptirler.” Bu şekilde Onlar İlk Neden'in amacını taklit edebilirler. Erdemli şehrin de böyle olması gerekir. Çünkü onun da bütün kısımlarının, eylemleri ile makamlarına göre, İlk Yöneticilerinin amaçlarını taklit etmesi gerekir (Farabi, 1997: 104). Burada şehri Farabi'nin kozmolojik düşüncesinin arka fonundan görmekteyiz: Evrenin Tanrısal kurallarından toplumda insan davranışının kurallarının türetilmesi gerekir. İnsan hayatının modelini, kozmik düzen oluşturur. Evrende daha aşağı derecelerde bulunan varlıklar tarafından yukarı aleme ait varlıkların "taklit" edilmeleri ve bunun neticesi olan uyum, ideal şehirde de hüküm sürmelidir. "Cahil” şehirlerin görüşleri, gerçeklik hakkında yanlış bir felsefi yoruma ve yanlış metafiziğe dayanır. Farabi evrensel olarak geçerli olduğu düşünülen ve Müslüman olmayan toplumlara da uygulanması mümkün olan görüşler savunmaktadır (Walzer, 1997: 249).

7. "Erdemli şehrin yöneticisi herhangi bir insan olamaz.” Çünkü yöneticilik iki şeyle olur:

a. O insan, yöneticiliğe, yaratılışı ve doğası bakımından, yetenekli olmalıdır.

b. O insan, yöneticilikle ilgili iradi yatkınlık ve tutumları kazanmış olmalıdır. Bunlar ise doğası gereği yöneticiliğe yeteneği olan insanda gelişip ortaya çıkacaklardır. Öte yandan her sanat yöneticilik için uygun değildir; insanların çoğu doğaları gereği hizmet etmek için uygunsalar, sanatların çoğu da şehirde hizmet etmek için uygun olan sanatlardır. Sanatların bazıları herhangi başka bir şeyi yönetmeksizin sadece hizmet ederken, bazıları ise kimi sanatlara hizmet ederken başka bazılarını yönetir. Erdemli şehri yönetecek sanat bundan dolayı 
herhangi bir sanat olamayacağı gibi herhangi bir yatkınlığın neticesi de olamaz. Çünkü nasıl ki bir cins içindeki ilk yönetici bu cinsteki herhangi bir şey tarafından yönetilmezse erdemli şehrin ilk yöneticisinin sanatının da hizmetkâr bir sanat olması ve başka herhangi bir sanat tarafından yönetilmesi mümkün değildir. (Örneğin organların yöneticisi, başka herhangi bir organın kendisinin yöneticisi mümkün olmayan organdır. Parçalardan meydana gelen her bütün için bu geçerlidir.) Tersine ilk yöneticinin sanatı diğer bütün sanatların amacını gerçekleştirme yönünde hareket ettikleri ve erdemli şehrin bütün eylemlerinde kendisine yöneldikleri sanat olmak zorundadir.

8. Erdemli şehrin yöneticisi bir başka insanın hükmü, idaresi altına girmesi mümkün olmayan insandır. O, "mükemmelliğe ulaşmış ve bilfiil akıl ve bilfiil akılsal olmuş bir insandır." Onun hayal gücünün kuvveti daha önce anılan tarzda doğası gereği mükemmelliğin en son derecesine varmış ve böylece doğası gereği gerek uyanık halde, gerek uykudayken "Faal Akıl'dan tikelleri -oldukları gibi veya temsilî olarak- ve akılsalları -temsilî olarak- olmaya hazır hale gelmiştir." Bütün akılsalları kavramış olmasından dolayı, onun edilgen aklı (akl munfa'il) mükemmelliğe erişmiş ve bilfiil akıl, bilfiil akılsal olmuştur.

9. İnsanın kendisiyle insan olduğu ilk aşama, bilfiil akıl olmaya hazır olan kabul edici, alıcı doğal yeteneğin ortaya çıkmasıdır. Bu yetenek bütün insanlarda ortaktır. Onunla Faal Akıl arasında iki aşama vardır: "Edilgin aklın bilfiil akıl olması ve kazanılmış aklın meydana gelmesi” aşamaları. O halde bir insan olmanın ilk aşamaları ile Faal Akıl arasında iki aşama vardır. Mükemmel edilgin akılla doğal yetenek, madde ve görünüşün birbiriyle birleşmesinden meydana gelen bütünde olduğu gibi tek bir şey olduklarında ve bu insanın insanlık görünüşü bilfiil akıl haline gelen edilgin akılla aynı şeymiş gibi ele alındığında bu insanla Faal Akıl arasında ancak tam bir aşama kalmış olacaktır. Doğal yetenek bilfiil akıl olan edilgin aklın maddesi, edilgin akıl kazanılmış aklın maddesi, kazanılmıș akıl Faal Aklın maddesi kılındığında ve bütün bunlar bir ve aynı şeymiş gibi ele alındığında, bu insan, kendisine Faal Akl'1n indiği insan olur.

10. $\mathrm{Bu}$ hal onun akılsal kuvvetinin her iki kısmında, yani kuramsal ve uygulamalı kısımlarında ve hayal gücü kuvvetinde ortaya çıktığında, bu insan kendisine "vahiy" gelen insan olur. Tanrı, ona Faal Akl'ın aracılığıyla vahiy indirir. Böylece Tanrı tarafından Faal Akl'a taşan şeyi Faal Akıl kazanılmış akıl vasıtasıyla edilgin akla sonra hayal gücü kuvvetine geçirir. Bu insan Faal Akıl'dan edilgin akla taşan, feyz eden şeyle "bilge bir insan, bir filozof, tanrısal nitelikli bir akıl kullanan mükemmel bir düşünür," Faal Akıl'dan hayal gücü kuvvetine taşan, feyz eden şeyle de "bir peygamber, geleceği bildiren bir uyarıcı, halihazırda var olan tikeller hakkında bilgi veren bir haber verici” olur.

11. Bu insan, insanlığın en üst aşamasında, mutluluğun en yüksek derecesindedir. Onun ruhu, sanki Faal Akıl'la bir olmuştur. O, kendisiyle mutluluğun elde edilebileceği her eyleme vakıf olan bir insandır. Bu ise, bir yönetici olmanın şartlarından birincisidir. Ayrıca, bildiği her şeyi başkasının hayal gücünde en iyi şekilde canlandırma kudreti O'nun dilinde mevcut olmalıdır. O, insanları mutluluğa ve kendileriyle bu mutluluğun elde edildiği eylemlere en iyi bir şekilde yöneltme kudretine sahip olmalıdır. Buna ek olarak, bedenen, savaşla ilgili eylemleri yerine getirebilmesi için sağlam olmalıdır. Bahsi geçen bu kişi, başka bir insanın kendisinin üzerinde hükmünün bulunmadığı hakim kişidir. "O, imamdır, erdemli şehrin birinci başkanıdır, erdemli milletin hükümdarıdır, oturulan dünyanın tümünün hükümdarıdır" " (Farabi, 1997: 105-107). Farabi mükemmel insanı, hayal gücü yeteneğinde bulunan "peygambersi sezgisi" tarafından desteklenmesi mümkün olan teorik bir filozof olarak betimlemiştir. Onun birinci sorunu şimdi "ideal şehrin gerçek yöneticisinin bu mükemmel insanla aynı insan olduğunu ispat" etmektir. Farabi, artık filozofu bir metafizikçi ve bir sezgi sahibi insan olarak

\footnotetext{
${ }^{4}$ Farabi, devlet başkanlığında herhangi bir kavramda ısrar etmemektedir (Kars, 2006: 29).
} 
betimlemekte, ayrıca özellikle filozof olmayan teb'asının yöneticisi olarak vatandaşlarıyla olan ilişkisinde göz önüne almaktadır. Bu insan onları bir öğretmen, bir hatip, bir kanun koyucu olarak mutluluk ve gerçekliğe yöneltmek suretiyle düşünce ve eylemdeki mükemmelliğini ortaya koyar. Farabi’ye göre, Faal Akıl, "o insanî varlığın en yüksek düzeyinde insanın kazanmış olduğu en yüksek aklı" takdim etmekle ilgilidir. Bu insanın Faal Akıl'la temasının neticesi olarak insan zihnine dışardan gelen akıl İshak İbni Huneyn'in "kazanılmış akıl”" olarak karşıladığıdır. unsurlar:

Farabi’nin İslami dinsel "vahiy" kavramına ilişkin felsefi açıklamasında önemli

-İnsan ile yukarı dünya arasında aşkın bir aracı varlık olarak “Faal Akıl” ve

-Aşkın bilginin alıcısı olarak "kazanılmış akıl"dır.

Farabi, “felsefenin İlk Neden'i yerine 'Tanrı'yı geçirirken özel bir amaca sahip olmuş olmalıdır." Peygamber (nabi), akla tâbi olan olağanüstü gelişmiş hayal gücü yeteneğiyle seçkinleşmiş bir insandır. Sonrasında filozof- hükümdar olmak üzere tayin edilmiş olan mükemmel insan "imam" diye adlandırılmaktadır ve en yüksek filozofun "tanrısal ilham"1 insanla Tanrı arasında melekler aracılığıyla veya doğrudan özel türden bir ilişkiyi ifade eden "vahy" kökünden gelen kelimelerle ifade edilmektedir. Farabi, imamın bir tanımını dinsel alan içinde vermeyi amaçlamamakta felsefi bir cevap ortaya koymaktadır. "İmam" şüphesiz "halife" den daha genel bir kavramdır ve "imam" in müslüman olmayan bir tarzda anlaşılması da ihtimal dahilindedir. Walzer'e göre Farabi ilk yöneticisini imam olarak takdim ettiğinde okuyucularının Peygamber'in kendisini de (ancak ilk planda değil) düşünmelerini istemiştir. Aynı zamanda Hz. Muhammed'in kendisi de filozof, metafizikçidir. Sezgisel ve kanun koyucu nitelikleri de mevcuttur. Kur'an aynı zamanda bir hitabet eseri olduğundan felsefi gerçekliği Müslümanlara sembolik şekilde aktarmaktadır. Farabi "insanın 'kazanılmış akl'ı ile aşkın Faal Akıl arasında belli türden bir ilişkinin gerçekleştiğine" inanmaktadır. Öte yandan O, kesin olarak "ister Faal Akıl'la isterse İlk Neden'le herhangi bir gerçek mistik birleşmeyi reddetmektedir." İnsan dünyada en büyük mutluluğa, en üstün mükemmelliğine ulaştı̆̆1 zaman bile Faal Akl'ın derecesinin altında kalır (Walzer, 1997: 252-257). Farabi'nin ilk başkanda aradığı özelliklerin çoğu, genel inanca göre Yunan düşüncesinden özellikle de Platon'dan alınmıştır. İlk-Başkan'ın Faal Akıl'dan vahiy alması, bu özellikler arasında Farabi için orijinal olan ve onu Yunan düşüncesinden uzaklaştırırken İslam düşüncesine yaklaştıran noktadır. Farabi’ye göre, felsefi bir donanıma sahip olmak vahye muhatap olabilmek için şarttır, fakat felsefi donanıma sahip olan herkes peygamber değildir. Peygamberliğin ayırıcı niteliğini, vahiy almanın, (yani felsefi bir donanıma sahip olmanın) yanında alınan vahyi insanlara, anlayabilecekleri kalıp ve biçimler içerisinde sunma olgusu oluşturmaktadır. Halbuki filozoflukta böyle bir yön gerekli değildir. Peygamberin fillozofa üstünlügü bu noktadan kaynaklanmaktadır (Aydınlı, 1987: 300-301).

12. Kişiliğinde doğuştan sahip olduğu 12 doğal niteliği birleştiren bir insan ancak bu duruma ulaşabilir.

a. Bu niteliklerden biri, onun organları bakımından tam ve eksiksiz olması, bu organların kendisini, kendilerine ait eylemlerini gerçekleştirmeye yetenekli kılmalarıdır. Bu organlardan herhangi biri ile ilgili O eylem yapmak istediğinde bunu kolayca yapmalıdır (Farabi, 1997: 107). Dolayısıyla sağlık ve fiziksel liyakat vazgeçilmezdir. (Walzer, 1997: 260).

b. O kendisine söylenen her şeyi iyi anlama ve kavrama yeteneğine doğası gereği sahip olmalı, konuşan kişinin amacına veyahut bizzat şeyin kendisinin mantığına uygun olarak onu anlamalıdir.

c. Anladığı, gördüğ̈̈, duyduğu, kavradığı şeyi zihninde saklama yeteneğine sahip olmalı, hemen hemen hiçbir şeyi unutmamalıdır. 
ç. Uyanık ve çok zeki olmalı, bir şeyle ilgili en küçük bir kanıt gördüğünde kanıtın işaret ettiği yönde o şeyi kavramalıdır (Farabi, 1997: 107-108). Yani onun, çabuk ve kesin bir zekaya sahip olması gerekir (Walzer, 1997: 261).

d. Tam bir açıklıkla zihninde bulunan bir şeyi ifade edebilmesini sağlayabilecek güzel konuşma yeteneğine sahip olmalıdır.

e. Bilgi edinmeyi, öğrenmeyi sevmeli, ona kendini vermeli, öğrenmenin güçlüklerini yenmeli, içerdiği sıkıntılara katlanmalı, bunları yorucu, eziyet verici bulmamalıdır (Farabi, 1997: 108). Dolayısıyla filozof adayı entelektüel niteliklerinin yanında aynı zamanda incelemeyi, öğrenmeyi seven ve herhangi bir özel gayret sarf etmeksizin onları özümseyen biri olmas1 gerekir (Walzer, 1997: 261). sevmelidir.

f. Tabiatı gereği yalandan ve yalancılardan nefret etmeli, doğruluğu ve doğru insanları

g. "Tabiatı gereği yemek, içmek ve cinsel zevklerin peşinde koşmayan, onları arzulamayan biri olmalı, kumardan kaçınmalı, bu türden şeylerden doğan zevklerden nefret etmelidir." (Farabi, 1997: 108). Tabiatı gereği aşırılıklardan korunmuş, iç denetimi olan ve tensel zevklere ölçüsüz bir biçimde kendini kaptırmayan biri olması gerektiği söylenmektedir (Walzer, 1997: 261).

g. Yüksek ruhlu olmalı, şerefi, ululuğu sevmeli, ruhu tabii olarak çirkin ve aşağılık şeylerin üstünde olmalı, şeyler içinde en yüce olanlarına doğru yükselmelidir.

h. "Gümüş, altın ve benzeri cinsinden dünyevi amaçlar, şeyler onun nazarında değersiz şeyler olmalıdır" (Farabi, 1997: 108). Yani para ve diğer dünya ile ilgili nimetlerin ona hitap etmemesi gerekir (Walzer, 1997: 261).

1. Tabiatı gereği adaleti ve adil kişileri sevmelidir (Farabi, 1997: 108).

i. Sonra yapılmasını gerekli gördüğü şey konusunda dirençli, kararlı olmalı, korku ve irade zayıflığı göstermeksizin cesur bir biçimde onu gerçekleştirmelidir (Farabi, 1997: 108). Farabi, her türlü fiziksel mükemmellik, zihinsel ve ahlaksal liyakatın cesaret, kararlılık ve korkusuzlukla beraber bulunmadıkça yararsız olduğunu söylemektedir.

Farabi, ideal şehrin yöneticisini ve onun mümkün değişik şekillerini ele almaktadır. Tabiat bakımında oniki fiziksel, zihinsel ve ahlaksal özellikle ideal şehrin gelecekteki yöneticisinin donatılmış olması gerekir. Ancak bu olgunun kendisi zamanı geldiğinde ona zihinsel ve ahlaksal yargılama gücü vermek için yeterli olmayacaktır. "Yalnız başına tabiat onu mükemmel bir insan kılamayacağı gibi otomatik olarak ona bir filozof-hükümdar gibi davranma gücünü de vermeyecektir." (Walzer, 1997: 258-262).

13. Tek bir insanda bütün bu özelliklerin bir araya gelmesi zordur. Bundan dolayı "bu tabiî yaratılıştaki insanlara her çağda ancak bir defa tesadüf edilir." Eğer erdemli şehirde böyle bir insan bulunur ve o insan büyüdükten sonra sayılan şartlardan altısını yerine getirirse veyahut hayal gücü kuvveti aracılığı ile insanları uyarma yeteneği dışındaki beş tanesini yerine getirirse- yönetici bu insan olacaktır. Böyle bir insana herhangi bir zamanda rastlanamazsa, ancak daha önce bu şehirde birbirini aralıksız olarak takip eden bu türden bir yöneticiler kuşağ mevcut olmuşsa, bu insanların koydukları kurallar, kanunlar ve adetler benimsenir ve korunur (Farabi, 1997: 108-109).

"İlk yöneticiden daha sonra gelen yöneticide doğuşundan ve çocukluğundan itibaren bu oniki özelliğin bir araya gelmesi" ve büyüdükten sonra da onun aşağıdaki altı özellikle seçkinleşmesi gerekir (Farabi, 1997: 109):

a. Bir filozof olmalidir.

b. İlk yöneticilerin şehri kendileriyle yönettikleri, şehir için vazettikleri, kanunları, kuralları, usulleri bilmeli, korumalı, bütün eylemlerinde bu yöneticilerin izinden gitmelidir.

c. Bir konuda eskilerin kanunlarının kaydedilmemiş olması durumunda, onların yollarını izleyerek yeni kanunlar çıkarsama, koyma konusunda üstün olmalıdır. 
ç. Onlardan sonra herhangi bir zamanda ortaya çıkan olaylar ve şeyler hakkında ilk yöneticilerin kendileriyle ilgili olarak herhangi bir kanun koymalarının mümkün olmadığ1 durumlarda doğru hüküm vermek üzere akıl yürütme gücüne ve üstün bir pratik akla sahip olmalidir.

d. İlk yöneticilerin kanunlarıyla onların yolunu izleyerek kendisinin çıkarmış olduğu yeni kanunlar hakkında halkı sözle aydınlatma, onlara kılavuzluk etme üstünlügüne sahip olmalidir.

e. Hem hizmet edici hem yönetici savaş sanatlarında usta olarak savaş fiillerini gerçekleştirmek için bedenen sağlam olmalıdır.

14. "Eğer bütün bu şartları kendisinde bir araya getiren tek bir kişi bulunmaz da biri sadece filozof olan, diğeri ise geri kalan şartları yerine getiren iki kişi bulunursa, onların ikisi bu şehrin yönetici olacaklardır." (Farabi, 1997: 109). Farabi, "aynı şehir içinde birden fazla filozof-hükümdarın birlikte yönetimini" bir imkan olarak bahsetmekte ancak onu geliştirmemektedir. Farabi, "tek bir yeterli yöneticinin mevcut olmaması durumunda, bir tür iki kişinin yönetimini (diarchy) tesis etmeyi”" teklif etmektedir. Bu türden bir ikili hükümdarlığın herhangi bir tarihi örneğini bulmak güçtür. Farabi'nin bu tür bir ikili yönetim fikri kendi zamanında (Örneğin Amiri tarafından) ciddiye alınmıştır (Walzer, 1997: 262-266). Eğer bu şartlar, farklı insanlar arasında felsefe birinde, ikinci özellik ikinci bir insanda, üçüncü özellik üçüncü bir insanda, dördüncü özellik dördüncü bir insanda, beşinci özellik beşinci bir insanda, altıncı özellik altıncı bir insanda olmak üzere dağılmış ve bütün bu insanlar birbirleriyle anlaşmış olurlarsa, onların hepsi birlikte en üstün yöneticiler olacaklardır. Ancak, herhangi bir zamanda eğer yönetimin bir parçası olmaktan felsefe çıkarsa, bu yönetimde bütün diğer şartlar mevcut olsa bile, erdemli şehir hükümdarsız kalmış olacak, şehrin yönetimi ile uğraşan kişi bir hükümdar olmayacak, şehir halkı helak olma tehlikesiyle karşı karşıya kalacaktır. Eğer bu şehrin fiilî yöneticisine bağlı olacak bir filozof bulunmazsa, belli bir süre sonra o şehir yok olmakta gecikmeyecektir (Farabi, 1997: 110). Bu ikinci başkanın halife ile birçok ortak noktası olduğu apaçıktır. Her ikisinin özellikleri arasındaki yakınlık terminoloji yakınlığının daha ötesinde öze kadar gider. Farabi'nin, Arâ'da savaşın karşılığı olarak harbi, Fusûl'de ise cihad kelimesini kullanması Rosenthal'e göre farklı amaç ve muhataplar için yazılmasıyla açıklanabilir. Her ne kadar Farabi'nin zihninde Müslümanlar ilk planda olsalar da Arâ'da müslümanlarla sınırlı kalmaz ve felsefe ile ilgilenen daha geniş bir çevreyi muhatap alır (Rosenthal, 1996: 192-193). Rosenthal'ın yorumu biraz aşırı olmakla beraber dikkate değerdir. Öte yandan Farabi görüşlerini sadece müslüman dünya ile sınırlandırmaz, herkes için bir rolmodel oluşturmaya çalışır. Farabi, ister filozof-peygamber isterse sadece filozof olsunlar bu tür olağanüstü insanların ortaya çıkışının az rastlanır bir olay olduğunu kabul etmekteydi. O bunun geçmişte fiilen gerçekleşmiş olduğunu düşünmektedir. Bununla beraber çok yakın bir gelecekte onun tekrar edeceği konusunda çok ümitvar olmadığı gibi tekrar ortaya çıkabileceği konusunda da şüpheleri mevcuttur. Felsefeyi aktüel idareye bağlamak konusunda ümitsiz değildir. Bundan dolayı o dikkatini ikinci ve üçüncü en iyi yönetime çevirmekte ve programını gerçekleştirmek üzere gerçek hayatta kendisine sunulmuş olan imkanları göz önüne almaktadır. Farabi soyut kavramlarla ayrıntıları açıklamaktadır (Walzer, 1997: 262-266). Farabi’ye göre, her ne ölçüde yasal mekanizmaları ya da töreleri değişse de erdemli şehir birdir (Yıldız, 2009: 209). Farklı zamanlarda birbirlerini takip ederek erdemli şehirlere hükümdar olan kişiler sanki tek bir ruh, her zaman aynı kalan tek bir hükümdar gibidirler (Farabi: 1997: 112-113):

Aynı zamanda tek bir şehirde veya birçok şehirde hüküm süren birden çok hükümdar olduğu durumda da onların hepsi aynı şekilde sanki tek bir hükümdar, ruhları da tek bir ruh gibidir. Böyle bir şehrin her bir sınıfına mensub olan ve farklı zamanlarda birbirini takip eden insanlar da sanki her zaman aynı kalan tek bir ruh gibidirler. Aynı şekilde aynı zamanda yaşayan, ister bir şehirde, ister bir çok şehirde olsunlar bir aynı sınıfa mensup olan insanların ruhları, bu sınıf ister âmir bir sınıf, ister hizmetkâr bir sınıf olsun, yine sanki tek bir ruh gibidir. 
Farabi şehrin sürekliliğini kişilere ve yasal düzeneğe bağlamaz. Kişiler gelip geçicidir, yasalar da zamanın şartlarına göre değişebilir. Süreklilik, "erdemli şehrin amacında ve bu amaca ulaşmak için gerekli olan araçların" değişen şartlara göre sağlanmasıdır. Bu da felsefenin şehir yönetiminde gereğini gösterir (Yıldız, 2009: 210). Her şehrin, erdemli şehir olma gibi bir zorunluluğu yoktur. Nitekim erdemli (mükemmel) şehirlere zıt olan şehirler de mevcuttur (Çetinkaya, 2006a: 43).

Erdemli şehrin yalnızca bir şekli bulunmaktadır. Erdemsiz şehirler dörde ayrılır (Kaya, 2010: 19). Bu şehirler şunlardır:

-Câhil şehir

-Bozuk (fâsık) şehir

-Karakteri değişmiş (mubaddala) şehir

-Doğru yolu bulamamış, yanlışlık içinde olan (dâlla) şehir

Bu değişik şehirlerin halkı da erdemli şehre zıttır. Cahil şehir bir sürü başka şehre de ayrılır. Bunlar zarûret șehri, zenginlik şehri, bayağılık (hassa) ve düşüklük (sukût) şehri, șeref (karâma) şehri, kuvvet (tagallub) şehri, demokratik (cima'iyya) şehirdir (Farabi, 1997: 110111).

\section{Sonuç}

Farabi, El-Medinetü'l Fâzıla isimli eserinde lider merkezli bir yönetim anlayışı ile etik bir yönetimin kurulabileceğini ileri sürer. Ona göre iki tür şehir vardır: Erdemli olanlar ve olmayanlar. (Özmen, 2014: 191) Farabi'nin felsefi analizler yapma yoluna giderek şehir kavramına açıklık getirmeye çalışması, eserde dikkat çeken önemli bir noktadır. Örneğin; ilk Varolan ile şehrin yöneticisi arasında, insan bedeni ile devlet arasında kurmuş olduğu organik bağlar dikkate değerdir. Şehir kuramını organizmacı bir görüşten hareket ederek açıklamaya çalışmıştır. Erdemli şehir eseri Türk-İslam düşünce hayatında önemli bir yer tutmaktadır. Eserin önemini arttıran başlıca unsurlardan biri; Farabi'nin felsefi görüşleriyle kurguladığı toplumşehir ilişkisini son derece açık bir biçimde anlatmasıdır. Bunun yanı sıra İslam felsefesi ile Antik Yunan felsefesi arasındaki karşılıklı etkileşimi ortaya koyması "İdeal Şehir" i önemli kılan bir başka nedendir (Demirel, 2014: 359).Platon ve Aristo, siyasi ideal sahasında polis, site-devlet mefhumundan ileri gidememiştir. İnsanlık tarihinde milli devletlerin üstünde bütün milletleri kapsayan milletler arası devlet tasavvurunu, idealini ilk defa olarak açık ve sarih bir şekilde Farabi ileri sürmüştür.Farabi'nin şehir başkanlarında gereken nitelikler hakkındaki fikirleri de çok orjinaldir. Bu alanda da yepyeni bir görüş öne sürmektedir. Farabi'ye göre şehrin iyi veya kötü olması ancak halkın idareye katılımının derece ve şekilleriyle değil, şehri idare eden şeflerin nitelik ve yetenekleriyle de alakalıdır. Farabi'nin bu alandaki araştırmalarının esası yöneticilerin nitelikleridir. Yönetimde en önemli unsurun reislerin (başkanların) nitelikleri olduğuna dair hakikati ilk defa olarak açıklık ve kuvvetle ileri süren de Farabi olmuştur (Arsal, 1945: 624-634).

Özetle;

- İnsan toplumsal bir varlıktır.

- Mükemmel toplumlar üç çeşittir: Büyük, orta ve küçük

- İlkin ancak şehirde en üstün iyiliğe ve mükemmelliğe ulaşılabilir.

- Mükemmel şehir tam ve sağlıklı bedene benzer.

- Herhangi bir insan erdemli şehrin yöneticisi olamaz.

- Erdemli şehrin yöneticisi bir başka insanın hükmü altına girmesi imkansız kişidir.

- Doğuştan bahsi geçen oniki niteliğe sahip olan insan ancak bu duruma ulaşabilir. Tek bir insanda bütün özelliklerin bir araya gelmesi güçtür. Ondan dolayı felsefe önem arz etmekle beraber şartlar biraz hafifletilir. 


\section{REFERENCES}

- $\quad$ Ateş, A. (1990). Notlar. Farabi içinde, Îhsâ'ül-Ulûm (İlimlerin Sayımı), 140-156.

- Aydınlı, Y. (1987). Fârâbî’nin Siyaset Felsefesinde ‘ilk-Başkan (er-Reîs el-Evvel)’ Kavramı. Uludağ Üniversitesi İlahiyat Fakültesi, 291-302.

- Çetinkaya, B. A. (2006a). Mutlu İnsanların Coğrafyası Erdemli Şehir. Somuncu Baba, Aylık İlim - Kültür ve Edebiyat Dergisi, 40-43 .

- Çetinkaya, B. A. (2006b). Erdemli Yönetim ve Erdemli Reis / Başkan. Somuncu Baba, Aylık İlim - Kültür ve Edebiyat Dergisi, 40-43 .

- Çınar, A. A. (2001). Farabî Felsefesi ve Ahmet Yesevî ‘nin Kültür Kimliğine Etkisi. Milli Folklor, Üç Aylık Uluslar Arası Halkbilimi Dergisi, 77-80.

- Danışman, N. (1990). Önsöz. Farabi içinde, El - Medinetü'l Fâzıla, (Çeviren: Nafiz Danışman). İstanbul: Milli Eğitim Bakanlığı Yayınları: 1152.

- Demirel, D. (2014). Fârâbi'nin İdeal Devleti: Erdemli Şehir. Niğde Üniversitesi İ̈BF Dergisi, 358-369.

- Fârâbi. (1997). İdeal Devlet, El-Medînetü'l-Fâzıla (Mabâdı’ Arâ Ahl Al-Madına Al-Fâdıla (Çeviren: Ahmet Arslan). Ankara: Vadi Yayınları.

- http://kuran.diyanet.gov.tr/ . (Erişim Tarihi: 12.12.2014)

- Kars, Z. (2006). Fârâbî’de İnsan-Devlet İlişkisi. Atatürk Üniversitesi Sosyal Bilimler Enstitüsü Dergisi, 21-37.

- Kaya, M. (2010). Erdemli Devletin Çatısını Kurdu. Dil ve Edebiyat Dergisi, 13-19.

- Keklik, N. (1969). İslâm Mantık Tarihi, İslâm Mantığının Kaynakları Süryânîlerde Mantık ve İslâm Mantıkçıları, I. Cild. İstanbul: İstanbul Üniversitesi Edebiyat Fakültesi Yayınları.

- Olguner, F. (1987). Fârâbî. Ankara: Kültür ve Turizm Bakanlığı Yayınları: 748, Türk Büyükleri Dizisi: 29, Gaye Matbaacılık.

- Rosenthal, E. I. (1996). Ortaçağda İslam Siyaset Düşüncesi (Çeviren: Ali Çaksu). İstanbul: İz Yayınc1lik.

- Şahin, E. (2010). Platon ve Fârâbî’de Aristokrasi. Ankara Üniversitesi İlahiyat Fakültesi Dergisi, 111-130.

- Şirvani, H. H. (1950). Fârâbî’nin Siyasî Nazariyeleri. (Çev. Hüseyin G. Yurdaydın). Ankara Üniversitesi Dil ve Tarih-Coğrafya Fakültesi Dergisi, 441-458.

- Vural, B. (2010). Platon ve Farabi’nin Siyaset Felsefelerinde İdeal Yönetim (Yayınlanmamış Yüksek Lisans Tezi). Kırıkkale: Kırıkkale Üniversitesi Sosyal Bilimler Enstitüsü. 
- Walzer, R. R. (1985). Al-Fârâbî on the Perfect State (Abu Nasr al- Fârâbî’s Mabâdi Arâ Ahl al-Madîna al-Fâdıla), A revised text with introduction, translation and commentary. Oxford: Clarendon Press.

- Walzer, R. R. (1997). Açılama-Yorumlar. Fârâbi içinde, İdeal Devlet, El-Medînetü'l-Fâzıla (Mabâdı’ Arâ Ahl Al-Madına Al-Fâdıla), (Çeviren Ahmet Arslan) (s. 145-341). Ankara: Vadi Yayınları.

- Yıldız, M. (2009). Farabi’nin Toplum ve Devlet Görüşü (Yayınlanmamış Doktora Tezi). Kayseri: Erciyes Üniversitesi Sosyal Bilimler Enstitüsü. 